\title{
Marinitoga camini gen. nov., sp. nov., a rod-shaped bacterium belonging to the order Thermotogales, isolated from a deep-sea hydrothermal vent
}

\author{
Nathalie Wery, $†$ Françoise Lesongeur, Patricia Pignet, \\ Véronique Derennes, $¥$ Marie-Anne Cambon-Bonavita, Anne Godfroy \\ and Georges Barbier
}

Laboratoire de Caractérisation des Microorganismes Marins, Département de Valorisation des Produits, IFREMER, Centre de Brest, BP 70, 29280 Plouzané, France
Author for correspondence: Nathalie Wery. Tel: +44 1225826407 Fax: +44 1225826779. e-mail: bssnaw@bath.ac.uk

\begin{abstract}
A thermophilic, anaerobic, chemo-organotrophic sulfur-reducing bacterium, designated MV1075', was isolated from a deep-sea hydrothermal chimney sample collected on the Mid-Atlantic Ridge. Cells were rod-shaped with a sheath-like outer structure, motile with polar flagella and stained Gramnegative. They appeared singly, in pairs or in short chains. The temperature range for growth was $25-65{ }^{\circ} \mathrm{C}$, with an optimum at $55^{\circ} \mathrm{C}$. Growth was observed from $\mathrm{pH} 5$ to $\mathrm{pH} \mathrm{9,} \mathrm{and} \mathrm{the} \mathrm{optimum} \mathrm{pH} \mathrm{was} \mathrm{around} \mathrm{7.} \mathrm{The} \mathrm{salinity}$ range for growth was 15-70 $\mathrm{g}$ sea salt $\mathrm{I}^{-1}$ (corresponding to $10-45 \mathrm{~g} \mathrm{NaCl} \mathrm{I}^{-1}$ ), with an optimum at $30 \mathrm{~g} \mathrm{I}^{-1}\left(20 \mathrm{~g} \mathrm{NaCl} \mathrm{I}^{-1}\right)$. The isolate was able to grow on a broad spectrum of carbohydrates or complex proteinaceous substrates. Sulfur was not necessary for growth. Growth was inhibited by $\mathrm{H}_{2}$, but, in presence of sulfur, this inhibition was removed and $\mathrm{H}_{2} \mathrm{~S}$ was produced. The $\mathrm{G}+\mathrm{C}$ content of the genomic DNA was 29 mol\%. Phylogenetic analyses of the 16S rRNA gene located the strain within the order Thermotogales, in the domain Bacteria. On the basis of 165 rDNA sequence comparisons, in combination with morphological and physiological characteristics, it is proposed that the isolate should be described as a novel species of a new genus, Marinitoga gen. nov., of which Marinitoga camini sp. nov. is the type species. The type strain is MV1075' $\left(=\right.$ CNCM I-2413 $^{\top}=$ DSM $\left.^{13578^{\top}}\right)$.
\end{abstract}

Keywords: deep-sea hydrothermal vent, thermophile, Thermotogales, Marinitoga camini

\section{INTRODUCTION}

The order Thermotogales was first described as an order containing hyperthermophilic and extremely thermophilic bacteria (Huber \& Stetter, 1992). This order was then expanded by the discovery of new species, extending both the temperature and salinity ranges for growth. Currently, it contains thermophilic

\footnotetext{
† Present address: Department of Biology and Biochemistry, University of Bath, South Building, Claverton Down, Bath BA2 7AY, UK.

¥Present address: Institut des Sciences et Techniques de I'Ingénieur d'Angers 62, avenue Notre Dame du Lac, 49000 Angers, France.

The EMBL accession number for the $16 \mathrm{~S}$ rRNA sequence of strain MV1075 is AJ250439.
}

bacteria growing at up to $90{ }^{\circ} \mathrm{C}$, such as Thermotoga maritima, as well as moderate thermophiles such as Geotoga subterranea, which grows at an optimum temperature of $45^{\circ} \mathrm{C}$. The order Thermotogales is represented by five genera: Thermotoga, Thermosipho, Fervidobacterium, Geotoga and Petrotoga. The strains have various origins: oil-producing wells or oil reservoirs (Davey et al., 1993; Jeanthon et al., 1995; Ravot et al., 1995a; Lien et al., 1998), geothermally heated continental waters (Patel et al., 1985; Windberger et al., 1989; Huber et al., 1990; Andrews \& Patel, 1996; Friedrich \& Antranikian, 1996) and geothermally heated marine waters (Huber et al., 1986, 1989; Jannasch et al., 1988; Antoine et al., 1997). Duckworth et al. (1996) have also isolated an an- 
aerobic thermophile from a soda lake, and have proposed that it could be assigned to a new genus within the order Thermotogales because of its $16 \mathrm{~S}$ rDNA sequence and its alkaliphilic phenotype. Among the described species of the Thermotogales, only Thermosipho melanesiensis was isolated from deep-sea hydrothermal vents. It was isolated from the gills of a deep-sea hydrothermal vent mussel from the Lau Basin (south-western Pacific Ocean) (Antoine et al., 1997). Other anaerobic, heterotrophic sulfur-reducing strains were isolated from deep-sea vents and assigned to the genus Thermotoga (Marteinsson et al., 1997).

Members of the order Thermotogales are studied for their industrial applications in the production and use of thermophilic enzymes. Xylanolytic enzymes or amylases are located inside the 'toga' of some Thermotoga species and Petrotoga mobilis (Sunna \& Antranikian, 1996; Lien et al., 1998). Thermostable cellulases, $\beta$-glucosidases, $\alpha$-galactosidase, $\beta$-mannanase and $\beta$-mannosidase were also found in some Thermotoga species (Liebl et al., 1996; Duffaud et al., 1997; Zverlov et al., 1997). Fervidobacterium pennivorans was isolated for its ability to degrade native feather meal, and a thermostable keratinase was purified (Friedrich \& Antranikian, 1996). Amylolytic and pullulanolytic activities were also detected in this strain (Canganella et al., 1994; Bertoldo et al., 1999).

In September 1997, samples were collected from deepsea vent fields of the Azores Triple Junction, on the Mid-Atlantic Ridge. In this paper, we report the isolation, from one of these samples, and characterization of a novel rod-shaped bacterium belonging to the order Thermotogales.

\section{METHODS}

Collection of samples. Samples were collected by the manoperated submersible Nautile during the MARVEL cruise, on the following deep-sea vent fields on the Mid-Atlantic Ridge: Lucky Strike $\left(32^{\circ} 16^{\prime} \mathrm{W}, 37^{\circ} 17^{\prime} \mathrm{N} ;-1600\right.$ to $-1700 \mathrm{~m})$ and Menez-Gwen $\left(31^{\circ} 31^{\prime} \mathrm{W}, 37^{\circ} 51^{\prime} \mathrm{N}\right.$; -800 to $-1000 \mathrm{~m}$ ). Samples of chimney wall, rock debris and mussels were collected using an insulated box filled with sterilized water. Samples were sheltered in an anaerobic chamber and stored at $4{ }^{\circ} \mathrm{C}$ in serum vials filled with sterile sea water under anaerobic conditions $\left(\mathrm{N}_{2}\right.$ headspace gas and $0 \cdot 5 \mathrm{~g}$ sodium sulfide $1^{-1}$ ).

Growth conditions. Most of the experiments were performed on the enrichment medium YPCS, but the media YGS and YTS were also used. YPCS medium contained the following $\left(1^{-1}\right)$ : $0.5 \mathrm{~g}$ yeast extract (Difco), $1 \mathrm{~g}$ peptone (Difco), $5 \mathrm{~g}$ cellobiose (Sigma), $10 \mathrm{~g}$ sulfur (Prolabo), $30 \mathrm{~g}$ sea salt (Sigma), 6.05 g PIPES buffer (Sigma) and $1 \mathrm{mg}$ resazurin (Sigma). YGS medium contained the following $\left(1^{-1}\right): 1 \mathrm{~g}$ yeast extract, $2.5 \mathrm{~g}$ glucose (Sigma), $10 \mathrm{~g}$ sulfur, $30 \mathrm{~g}$ sea salt, $6.05 \mathrm{~g}$ PIPES buffer and $1 \mathrm{mg}$ resazurin. In YTS medium, the glucose was replaced by $2 \mathrm{~g}$ tryptone $1^{-1}$. YPC and YG media were YPCS and YGS media, respectively, but without the sulfur. YGC medium was YGS medium in which the sulfur was replaced by $10 \mathrm{~g}$ cystine $\mathrm{l}^{-1}$. The $\mathrm{pH}$ was adjusted to $7 \cdot 5$ in YPCS medium and to 7 in the other media. The media containing sulfur were sterilized at $100{ }^{\circ} \mathrm{C}$ for $30 \mathrm{~min}$ on two successive days. When sulfur was omitted, sterilization was obtained after $20 \mathrm{~min}$ at $121{ }^{\circ} \mathrm{C}$. Sterile media were transferred into an anaerobic chamber containing $\mathrm{N}_{2} / \mathrm{H}_{2} / \mathrm{CO}_{2}(90: 5: 5)$, reduced by the addition of sodium sulfide to a final concentration of $0.5 \mathrm{~g} \mathrm{l}^{-1}$, and then distributed into Hungate tubes $(6 \mathrm{ml}$ in a total volume of $20 \mathrm{ml})$ or in serum vials with butyl rubber stoppers $(20 \mathrm{ml}$ in a total volume of $60 \mathrm{ml}$ ). Unless indicated otherwise, cultures were incubated at atmospheric pressure under the anaerobicchamber gas mixture, at $50{ }^{\circ} \mathrm{C}$. All growth experiments were carried out in triplicate, except for analyses of organic acids and amino acids, which were performed in duplicate.

Enrichment and purification procedures. The enrichment procedure was performed using $1 \mathrm{ml}$ of the sheltered sample from the hydrothermal chimney inoculated into YPCS medium incubated at $65^{\circ} \mathrm{C}$ at atmospheric pressure under the anaerobic-chamber gas mixture. The presence of cells was revealed by microscopic observation. Cultures were purified by streaking enrichment samples onto the same medium solidified with Gelrite (Scott Laboratories) and incubating them at $65^{\circ} \mathrm{C}$ in anaerobic jars (Godfroy et al., 1997).

Storage. Cultures from the exponential growth phase were stored at $4{ }^{\circ} \mathrm{C}$. For long-term storage, cultures from the exponential growth phase were stored anaerobically in cryotubes at -20 and $-70{ }^{\circ} \mathrm{C}$, after the addition of DMSO $(5 \%, v / v ;$ Sigma $)$.

Observation of the culture and determination of cell numbers. Enumeration of cells was performed by means of direct cell counting using a Thoma chamber (depth, $0.02 \mathrm{~mm})$. Alternatively, cells were stained with $4^{\prime}, 6^{\prime}$ diamidino-2-phenylindole added directly to the samples at a final concentration of $1 \mathrm{mg} \mathrm{l}^{-1}$. Cells were observed with an Olympus model BH-2 microscope.

Morphology. Gram staining was realized using the Bacto 3step Gram stain Set-S (Difco). Endospores were examined by phase-contrast microscopy. For scanning electron microscopy, cells were fixed with $10 \%(\mathrm{v} / \mathrm{v})$ formalin for $1 \mathrm{~h}$ and then harvested by centrifugation for $20 \mathrm{~min}$ at $2000 \mathrm{~g}$. Pellets were resuspended in $23 \mathrm{~g} \mathrm{NaCl}^{-1}$, displayed on $0.22 \mu \mathrm{m}$ filters (Nucleopore) and dried overnight at room temperature. Samples were then coated with gold (SCD040; Balzers) and examined with an XL 30 LaB6 scanning electron microscope (Philips). For transmission electron microscopy, cells were harvested at the end of exponential phase. The pellet was resuspended and fixed for $1 \mathrm{~h}$ at room temperature in cacodylate buffer $[0.4 \mathrm{M}$ cacodylate, $\mathrm{pH} 7 \cdot 4$; $5.5 \%(\mathrm{w} / \mathrm{v}) \mathrm{NaCl} ; 8 \%(\mathrm{v} / \mathrm{v})$ glutaraldehyde; $2: 1: 1]$ and then post-fixed for $1 \mathrm{~h}$ at $4{ }^{\circ} \mathrm{C}$ in another cacodylate buffer $[0 \cdot 4 \mathrm{M}$ cacodylate, $\mathrm{pH} 7 \cdot 4 ; 10 \%(\mathrm{w} / \mathrm{v}) \mathrm{NaCl} ; 2 \%(\mathrm{w} / \mathrm{v})$ $\left.\mathrm{OsO}_{4} ; 1: 1: 2\right]$. After dehydration by immersion in different solutions with increasing ethanol concentrations, cells were embedded in Spurr's resin, thin-sectioned, contrasted with $1 \%(\mathrm{w} / \mathrm{v})$ uranyl acetate and $1 \%(\mathrm{w} / \mathrm{v})$ lead citrate (Bio$\mathrm{Rad})$ and then examined with an EM201 transmission microscope (Philips).

Analyses of amino acids, organic acids and aromatic acids. Each sample was centrifuged for $30 \mathrm{~min}$ at $8000 \mathrm{~g}$ to eliminate cell debris. Half of the supernatant was transferred to an ultrafree-CL-PLGC 10000 NMWL unit (Millipore) and centrifuged at $4500 \mathrm{~g}$ for several hours; $20 \mu \mathrm{l}$ of the filtrate was mixed with $30 \mu \mathrm{l}$ of ethanol/water/triethylamine $(2: 2: 1)$ and vacuum-dried. A derivatizing solution $(20 \mu \mathrm{l})$ 
containing ethanol/water/triethylamine/phenylisothiocyanate $(7: 1: 1: 1)$ was added and, after $10 \mathrm{~min}$ at room temperature, the sample was vacuum-dried. Analysis of amino acids by HPLC (Alliance 2690; Waters) was then performed using the conditions and products of the Waters PicoTag method (WAT007360; Waters). In the other part of the supernatant, proteins were precipitated with a $2 \%(\mathrm{w} / \mathrm{v})$ solution of 5 -sulfo-salicylic acid overnight at $4{ }^{\circ} \mathrm{C}$ and eliminated by centrifugation at $8000 \mathrm{~g}$ for $10 \mathrm{~min}$. The supernatant was then used for HPLC analyses of glucose, aromatic acids and linear organic acids. For glucose and linear organic acid analysis, $20 \mu \mathrm{l}$ supernatant was eluted on an $\mathrm{H}^{+}$exclusion column (polyspher OAKC 1.51270 ; Merck) at $60{ }^{\circ} \mathrm{C}$ with $9 \mathrm{mM} \mathrm{H}_{2} \mathrm{SO}_{4}$ at a flow rate of $0.35 \mathrm{ml} \mathrm{min}^{-1}$ and components were detected using a differential refractometer (refractometer 410; Waters). For analysis of aromatic acids, $20 \mu \mathrm{l}$ supernatant was eluted on an $\mathrm{H}^{+}$exclusion column (column 28352; Chrompack) at $65^{\circ} \mathrm{C}$ using $4.5 \mathrm{mM}$ $\mathrm{H}_{2} \mathrm{SO}_{4}$ at a flow rate of $0.5 \mathrm{ml} \mathrm{min}-1$ and components were detected by absorbance at $210 \mathrm{~nm}$ (UV detector 486; Waters).

Determination of growth parameters. To determine the optimum temperature for growth, cells were grown in Hungate tubes containing YPCS medium. Temperatures were maintained with aluminium heating blocks (Bioblock) and monitored with temperature probes placed in control tubes. To determine the effect of $\mathrm{pH}$ on growth, YPCS medium was modified by using the following buffers (Sigma), each at a concentration of $20 \mathrm{mM}$ : for $\mathrm{pH} \mathrm{2,} 3$ and 4, no buffer; for $\mathrm{pH} 5,5.5$ and 6, MES buffer; for $\mathrm{pH} 6.5$ and 7 , PIPES buffer; for $\mathrm{pH} 7.5$ and 8, HEPES buffer; for $\mathrm{pH} 8.5$ and 9, AMPSO buffer; for $\mathrm{pH} 10$, no buffer. In the anaerobic chamber, sodium sulfide was added and the $\mathrm{pH}$ was controlled at room temperature and adjusted, if necessary, with $0 \cdot 1 \mathrm{M} \mathrm{HCl}$ and $0 \cdot 1 \mathrm{M} \mathrm{NaOH}$. To determine the requirement for salt, YPCS medium was prepared with different concentrations of sea salt. The effects of temperature, $\mathrm{pH}$ and salinity were determined by measuring the cellular concentration when all of the different cultures were in the exponential phase of growth.

Determination of growth requirements. The ability of isolate MV1075 ${ }^{\mathrm{T}}$ to use various carbon sources was tested in medium containing the following $\left(1^{-1}\right): 30 \mathrm{~g}$ sea salt, $10 \mathrm{ml}$ mineral solution (Balch et al., 1979), $10 \mathrm{ml}$ vitamin solution

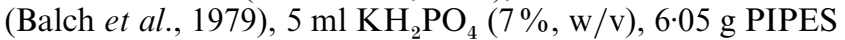
buffer and the carbon source. Carbohydrates were tested at $5 \mathrm{~g} \mathrm{l}^{-1}$, alcohols at $5 \mathrm{ml}^{-1}$ and acids at $2 \mathrm{~g} \mathrm{l}^{-1}$. Sugar and vitamin solutions were sterilized by filtration and added just before inoculation. For monosaccharides, polysaccharides, acids and alcohols, the medium was supplemented with $0 \cdot 1 \mathrm{~g}$ yeast extract $1^{-1}$ as the nitrogen source. The monosaccharides tested were: $\mathrm{D}(+)$-sucrose, $\mathrm{D}(+)$-glucose, $\mathrm{D}(-)$-fructose, maltose, $\mathrm{D}(+)$-cellobiose, $\mathrm{D}(+)$-mannose, $\mathrm{L}(-)$-sorbose, $\mathrm{D}(-)$-arabinose, $\mathrm{D}(+)$-galactose, $\mathrm{D}(+)$-xylose, lactose, $\mathrm{D}(-)$-ribose. The following polysaccharides were tested: starch, cellulose, carboxymethylcellulose, chitin, pectin, dextran and xylan. The following acids and alcohols were tested: glycerol, methanol, ethanol, formate, acetate, propionate, pyruvate, succinate and lactate. The other carbon sources, tested at $5 \mathrm{~g} \mathrm{l}^{-1}$, were as follows: yeast extract, brain-heart infusion (BHI), gluten, peptone, tryptone, beef extract, casein, collagen, keratin, elastin, albumin and Casamino acids. A solution of 20 amino acids, each at $0 \cdot 1 \mathrm{~g}$ $1^{-1}$, and combinations of $1 \mathrm{~g}$ peptone $/ 0 \cdot 5 \mathrm{~g}$ yeast extract $1^{-1}$ and $1 \mathrm{~g}$ tryptone $/ 0 \cdot 5 \mathrm{~g}$ yeast extract $1^{-1}$ were also tested as carbon sources. Nitrogen sources were tested with $5 \mathrm{~g}$ glucose $1^{-1}$ as the carbon source. Peptone, yeast extract, tryptone and $\mathrm{BHI}$ were tested at $0 \cdot 1 \mathrm{~g}^{-1}$; sodium nitrate, urea and $\mathrm{NH}_{4} \mathrm{Cl}$ were tested at $10 \mathrm{mM}$. Tests were performed in serum vials. To avoid growth on the substrates carried over with the inoculum, positive cultures were transferred once (10\% inoculum). The final concentration of cells was determined by direct counting and compared with the concentration in the control without the carbon or nitrogen source tested. Autotrophic growth with $\mathrm{H}_{2} / \mathrm{CO}_{2}(80: 20)$ gas as the sole carbon and energy source was also tested. To compare growth on sugar with growth on proteinaceous substrates, amino, organic and aromatic acids were analysed during cultivation on YGS and YTS media. The concentrations of amino acids and organic acids were compared with uninoculated medium. $\mathrm{H}_{2}, \mathrm{CO}_{2}$ and $\mathrm{H}_{2} \mathrm{~S}$ were detected using an MTI micro-gas chromatograph equipped with a thermal conductivity detector. A molecular sieve with argon as the carrier gas and a temperature of $30^{\circ} \mathrm{C}$ were used to detect $\mathrm{H}_{2} . \mathrm{H}_{2} \mathrm{~S}$ and $\mathrm{CO}_{2}$ were determined using a paraplotU column, at $100{ }^{\circ} \mathrm{C}$, with helium as the gas carrier.

Effects of possible electron acceptors. The ability of the isolate to grow in the presence of different electron acceptors was tested on YPC medium. Sulfur and cystine were tested at $10 \mathrm{~g} \mathrm{l}^{-1}$, polysulfides at $10 \mathrm{mM}$ (Blumentals et al., 1990) and thiosulfate at $20 \mathrm{mM}$. Tests were performed in Hungate tubes. Complementary analyses were performed to determine the effects of sulfur and cystine: the consumption and production of organic acids and amino acids were determined on YG, YGC and YGS media. The variations in concentration of amino acids and organic acids were compared with the concentrations in uninoculated media.

Influence of the gas headspace. To test the influence of the gas composition of the headspace, cells were cultured on YG and YGS media with various headspace gases, as follows: $\mathrm{N}_{2}, \mathrm{~N}_{2} / \mathrm{CO}_{2}(80: 20), \mathrm{H}_{2} / \mathrm{CO}_{2}(80: 20)$ and $\mathrm{N}_{2} / \mathrm{H}_{2} / \mathrm{CO}_{2}$ $(90: 5: 5)$. The production of $\mathrm{H}_{2} \mathrm{~S}$ was examined using lead acetate paper (Whatman).

Susceptibility to antibiotics. Susceptibility to antibiotics at $50 \mu \mathrm{g} \mathrm{ml}^{-1}$ was investigated. Concentrated solutions of antibiotics were added to YPCS medium just before inoculation. When the antibiotic was diluted in ethanol (chloramphenicol) or DMSO (rifampicin), the same volume of solvent was added to control cultures. When the strain was insensitive, the concentration of antibiotic was increased to $100 \mu \mathrm{g} \mathrm{ml}^{-1}$; when it was sensitive, susceptibility at $25 \mu \mathrm{g} \mathrm{m} \mathrm{l}^{-1}$ was determined.

DNA extraction and purification. Genomic DNA was extracted by the following procedure. Aliquots ( $200 \mathrm{ml}$ each) of late-exponential-phase culture were harvested at $10000 \mathrm{~g}$ for $30 \mathrm{~min}$, washed in $23 \mathrm{~g} \mathrm{NaCl} \mathrm{l}^{-1}$ and resuspended in $5 \mathrm{ml}$ lysis buffer $(100 \mathrm{mM}$ Tris $/ \mathrm{HCl}, 100 \mathrm{mM} \mathrm{NaCl}, 50 \mathrm{mM}$ EDTA; pH 8). SDS (1\%, w/v) was added; cell lysis was immediate. One phenol/chloroform/isoamyl alcohol $(24: 24: 1)$ extraction was performed and the aqueous phase was treated with RNase A (30 $\mu \mathrm{g} 1^{-1}$ final) for $1 \mathrm{~h}$ at $60{ }^{\circ} \mathrm{C}$. A second phenol/chloroform/isoamyl alcohol (24:24:1) extraction and a chloroform extraction were then performed. The DNA was precipitated by adding 2 vols absolute ethanol at $-20{ }^{\circ} \mathrm{C}$ and resuspended in TE buffer $(10 \mathrm{mM}$ Tris $/ \mathrm{HCl}$, $2 \mathrm{mM}$ EDTA; $\mathrm{pH} \mathrm{7.4)}$ or in milliQ-sterilized water. The concentration and purity of the genomic DNA obtained were estimated using a GenQuant II spectrophotometer (Pharmacia) at $260 \mathrm{~nm}$. The quality of the extraction was checked on a $0.8 \%(\mathrm{w} / \mathrm{v})$ agarose gel containing $0.8 \mu \mathrm{g}$ ethidium bromide $\mathrm{ml}^{-1}$. 
DNA base composition. The DNA was purified by $\mathrm{CsCl}$ gradient centrifugation. After precipitation, the DNA was resuspended in TE buffer containing $1.075 \mathrm{~g} \mathrm{CsCl} \mathrm{ml}^{-1}$ and $10 \mathrm{mg}$ ethidium bromide $\mathrm{ml}^{-1}$ and then centrifuged in a preparative ultracentrifuge for $15 \mathrm{~h}$ at 65000 r.p.m. (rotor 70.1 Ti, model CO-L70K; Beckman). The DNA band was removed with a syringe. The ethidium bromide was then extracted using 2-propanol saturated with $\mathrm{CsCl}$. Finally, the solution was dialysed overnight against 1 litre TE buffer. The $\mathrm{G}+\mathrm{C}$ content of the DNA was determined by thermal denaturation (Marmur \& Doty, 1962) under the conditions reported by Raguénès et al. (1997). A calibration curve was obtained by using ultrapure DNAs from Escherichia coli strain B $(50 \mathrm{~mol} \% \mathrm{G}+\mathrm{C})$, Clostridium perfringens $(26.5$ $\mathrm{mol} \% \mathrm{G}+\mathrm{C})$ and Micrococcus luteus $(72 \mathrm{~mol} \% \mathrm{G}+\mathrm{C})$ as standards (Sigma).

Amplification of the 16S rDNA. The 16S rDNA was selectively amplified from purified genomic DNA by using a PCR with oligonucleotide primers designed to anneal to conserved positions in the $3^{\prime}$ - and $5^{\prime}$-regions of the $16 \mathrm{~S}$ rRNA genes. The bacterial forward primer SAdir (5'-AGAGTTTGATCATGGCTCAGA-3') corresponded to positions 828 of $E$. coli $16 \mathrm{~S}$ rRNA and the bacterial reverse primer S17rev (5'-GTTACCTTGTTACGACTT-3') corresponded to the complement of positions 1493-1509 of E. coli $16 \mathrm{~S}$ rRNA. The following components were combined in a total volume of $50 \mu \mathrm{l}$ : $100 \mathrm{ng}$ template DNA, $5 \mu \mathrm{l} 10 \times \mathrm{PCR}$ buffer $[100 \mathrm{mM}$ Tris $/ \mathrm{HCl}, \mathrm{pH} 9.0,50 \mathrm{mM} \mathrm{KCl}, 1.5 \mathrm{mM}$ $\mathrm{MgCl}_{2}, \quad 0.1 \% \quad(\mathrm{w} / \mathrm{v})$ Triton X-100, $0.2 \mathrm{ml}$ BSA or gelatin $\mathrm{ml}^{-1}$; Appligene-Oncor], 2.5 U Taq DNA polymerase (Appligene-Oncor), $200 \mu \mathrm{M}$ each dNTP, $2 \mathrm{mM}$ forward primer and $2 \mathrm{mM}$ reverse primer. The complete reaction mixture was overlaid with mineral oil (Sigma) and incubated in a 96-gradient thermocycler (Stratagene). The following temperature profile was used for PCR: $94{ }^{\circ} \mathrm{C}$ for $3 \mathrm{~min}$ and then 30 cycles of $94^{\circ} \mathrm{C}$ for $1 \mathrm{~min}, 50^{\circ} \mathrm{C}$ for $90 \mathrm{~s}$ and $72^{\circ} \mathrm{C}$ for $2 \mathrm{~min}$ and, finally, an extension step at $72^{\circ} \mathrm{C}$ for $6 \mathrm{~min}$. PCR results were analysed by electrophoresis on $0.8 \%(\mathrm{w} / \mathrm{v})$ agarose/TAE gels (0.04 M Tris/acetate, 0.001 M EDTA) containing $0.8 \mu \mathrm{g}$ ethidium bromide $\mathrm{ml}^{-1}$. All gel images were realized using a Fluor-S multiImager (Bio-Rad).

16S rDNA sequence analysis. The PCR product was sequenced using the primers described by Raguénès et al. (1996). This work was done at Euro Sequence Gene Service (France) with an automatic DNA-analysis system (Applied Biosystems); 1469 positions of the 16S rDNA were determined. The sequence was then compared with others available in GenBank, using the BLAST program (Altschul et al., 1990). A multiple-sequence file, corresponding to positions 33-1356 of E. coli $16 \mathrm{~S}$ rRNA, was obtained by using the MEGALIGN program of the DNASTAR package (Promega). Alignments and similarity levels were obtained by using the CLUSTAL $\mathrm{W}$ method with weighted residues (Thompson et al., 1994). Alignment was then performed manually using the multiple sequence alignment editor SEAVIEW. The phylogenetic reconstruction was produced using PHYLO_WIN (Galtier et al., 1996) with the following setup: the Jukes-Cantor distance matrix and, in succession, the neighbour-joining (Saitou \& Nei, 1987), maximum parsimony (Lake, 1987) and maximum-likelihood (Felsenstein, 1981) methods. Bootstrap values were determined according to Felsenstein (1985). The following 16S rDNA sequences (accession numbers in parentheses) were used for the phylogenetic analysis: Thermus thermophilus ATCC $27634^{\mathrm{T}}$ (TTHB27), Thermosipho africanus DSM 5309 ${ }^{\mathrm{T}}$ (M83140), Thermosipho melanesiensis CIP $104789^{\mathrm{T}}$ (Z70248), Thermo- toga hypogea DSM $11164^{\mathrm{T}}$ (U89768), Thermotoga elfii DSM 9442 ${ }^{\mathrm{T}}$ (X80790), Thermotoga subterranea DSM 5069 (U22664), Thermotoga maritima DSM 3109 ${ }^{\mathrm{T}}$ (Z11839), 'Thermopallium natronophilum' (X91822), Fervidobacterium nodosum ATCC 35602 ${ }^{\mathrm{T}}$ (M59177), Fervidobacterium islandicum DSM 5733 ${ }^{\mathrm{T}}$ (M59176), Fervidobacterium gondwanense ACM 5017 (Z49117), Geotoga petraea ATCC 51226 ${ }^{\mathrm{T}}$ (L10658), Geotoga subterranea ATCC 51225 (L10659), Petrotoga miotherma ATCC 51224 ${ }^{\mathrm{T}}$ (L10657) and P. mobilis DSM 10674 ${ }^{\mathrm{T}}$ (Y15479).

\section{RESULTS}

\section{Isolation}

During the MARVEL cruise, YPCS medium was inoculated with pulverulent mineral material from a chimney at the Menez-Gwen hydrothermal site $(-980 \mathrm{~m})$ on the Mid-Atlantic Ridge. The enrichment culture, incubated at $65^{\circ} \mathrm{C}$, contained non-motile, coccoid cells, single or in pairs, and also short rodshaped cells that were either single or in chains. After repeated streaking on solidified YPCS medium, isolated colonies were used to inoculate liquid YPCS medium. The two different morphologies were still observed in these cultures. PCR-RFLP analysis of the 16S rDNA (Antoine et al., 1995) revealed that the rodshaped cells were in a mixture with a Thermococcus species. Streaking on plates and serial dilutions $(1: 10)$ at $65^{\circ} \mathrm{C}$ in YPCS medium failed to separate the rodshaped cells from the coccoid cells. The rod-shaped bacteria were purified by subculturing at $40{ }^{\circ} \mathrm{C}$, without sulfur, diluted $1: 10$ every day for a week. The last subculture was purified by streaking on solidified YPCS medium. The isolate obtained was named MV1075 .

\section{Morphology}

Microscopic observation indicated that cells of isolate MV1075 ${ }^{\mathrm{T}}$ were motile rods that stained Gram-negative. Polar flagella were visible by scanning (Fig. 1) and

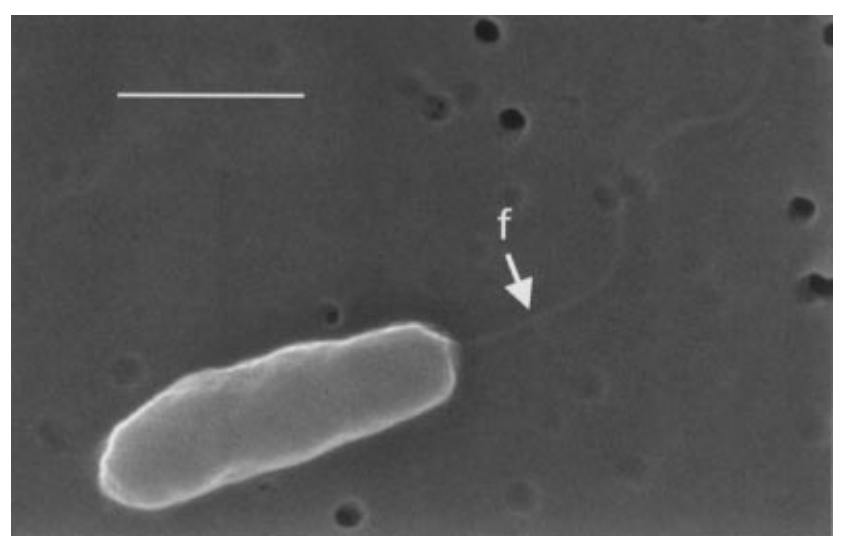

Fig. 1. Scanning electron micrograph of strain $\mathrm{MV} 1075^{\top}$, showing the flagellum (f). Bar, $1 \mu \mathrm{m}$. 

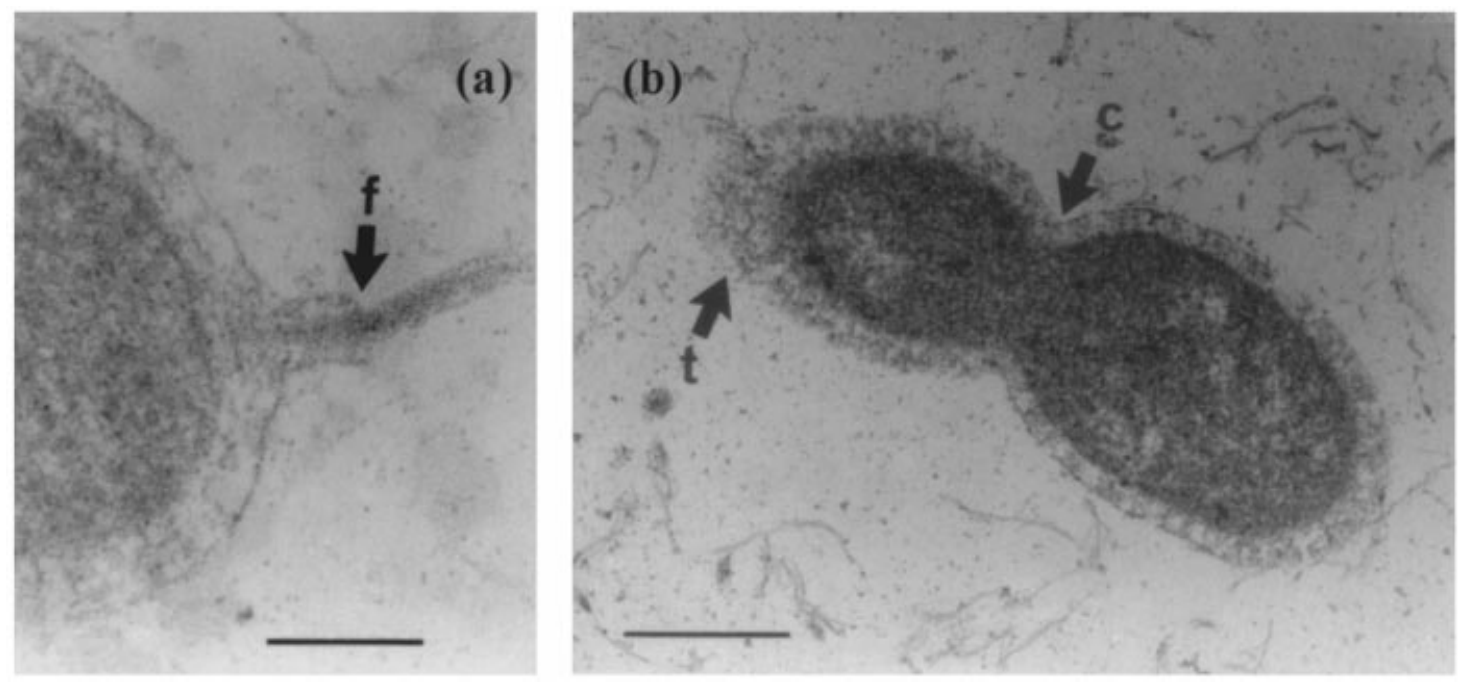

Fig. 2. Transmission electron micrographs of strain $M V 1075^{\top}$. (a) The flagellum ( $f$ ) and insertion point are shown. Bar, $0.2 \mu \mathrm{m}$. (b) Cells dividing by means of a constriction (c) and surrounded by a sheath-like membrane or 'toga' ( $\mathrm{t}$ ). Bar, $0.5 \mu \mathrm{m}$.
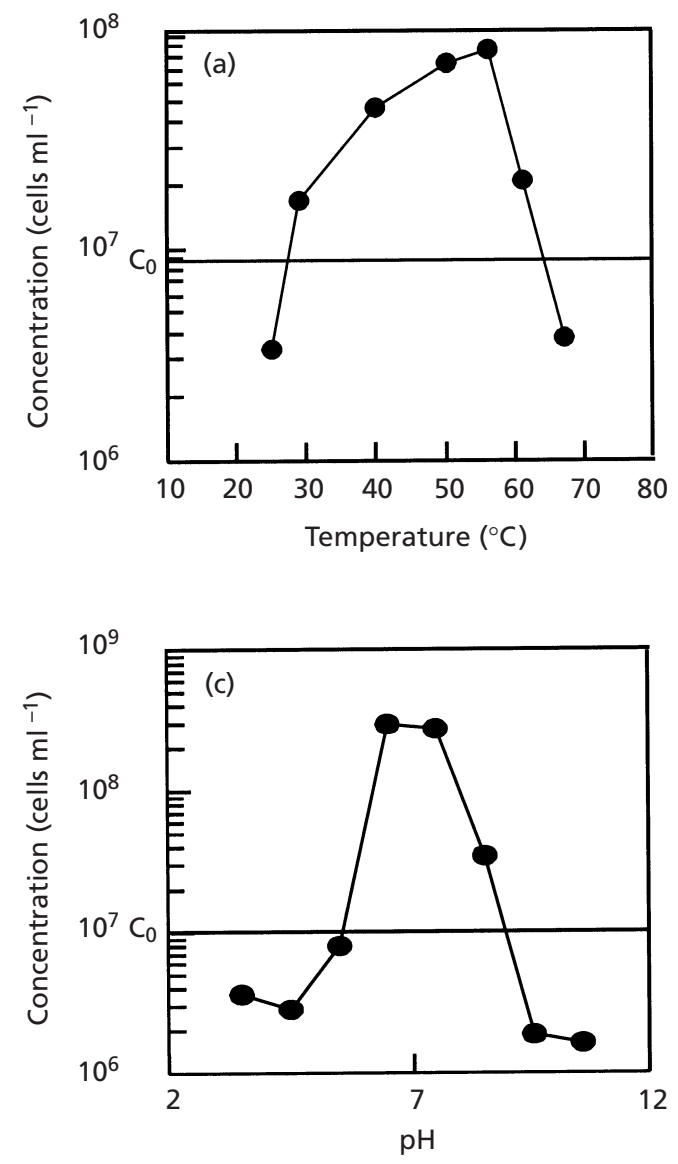

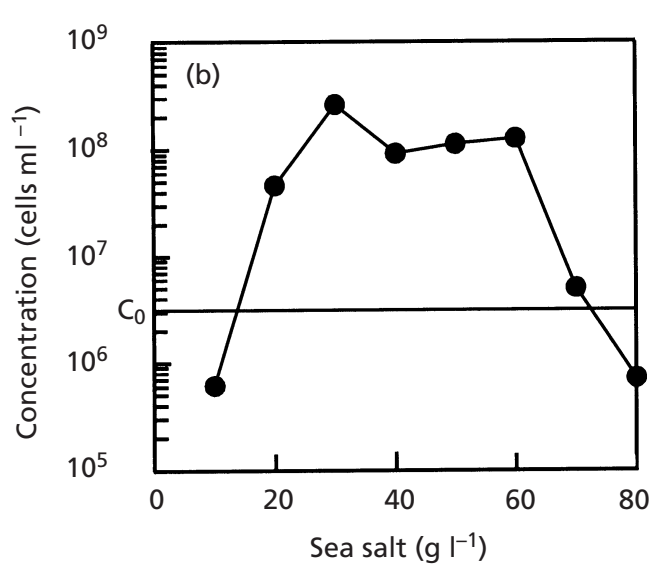

Fig. 3. Effects of (a) temperature $\left(\mathrm{pH} 7 \cdot 5,30 \mathrm{~g}\right.$ sea salt $\left.\mathrm{I}^{-1}\right)$, (b) salinity $\left(40{ }^{\circ} \mathrm{C}, \mathrm{pH} 7 \cdot 5\right)$ and (c) $\mathrm{pH}\left(40^{\circ} \mathrm{C}, 30 \mathrm{~g}\right.$ sea salt $\left.\mathrm{I}^{-1}\right)$ on the

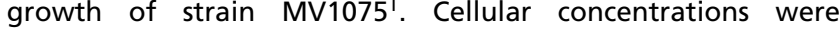
determined after 15 (a), 25 (b) and 30 (c) h. $C_{0}$ is the initial cell concentration of the cultures. transmission electron microscopy (Fig. 2a). Cells were surrounded by a 'toga', an outer sheath-like structure specific to members of the order Thermotogales (Fig.
$2 b)$. This envelope was visible in all phases of growth by phase-contrast microscopy. The cells appeared singly, in pairs or in chains within the sheath. The 
smaller single rods moved more rapidly than the longer cells. During the exponential growth phase under optimal conditions in YGS medium, the rods were $2-3 \mu \mathrm{m}$ long by $0 \cdot 5-1 \mu \mathrm{m}$ wide. The cells divided by constriction (Fig. 2b). During the stationary phase of growth, rods became shorter to spherical. Chains of up to 10 cells were occasionally observed. The cells grew longer and the proportion of chains increased under non-optimal conditions. Endospores were not observed in old cultures.

\section{Determination of growth parameters}

Isolate $\mathrm{MV} 1075^{\mathrm{T}}$ grew at $25-65^{\circ} \mathrm{C}$ and the optimum temperature for growth was around $55^{\circ} \mathrm{C}$ (Fig. 3a). Growth was observed at sea-salt concentrations ranging from 15 to $70 \mathrm{~g} \mathrm{l}^{-1}$ (corresponding to $10-45 \mathrm{~g}$ $\mathrm{NaCl}{ }^{-1}$ ), the optimum concentration being around $30 \mathrm{~g} \mathrm{l}^{-1}\left(20 \mathrm{~g} \mathrm{NaCl} \mathrm{l}^{-1}\right)$ (Fig. 3b). No growth was detected at salt concentrations of 10 or $80 \mathrm{~g}^{-1}$. At high salinity, i.e. $60-70 \mathrm{~g}$ sea salt $\mathrm{1}^{-1}$, changes in morphology were visible: motile, short, rod-shaped cells, single or in short chains, became longer and thinner and formed into non-motile, long chains. Growth was observed at pH 5-9, the optimum pH being around 7 (Fig. 3c).

\section{Growth requirements and metabolic products}

Strain MV1075 ${ }^{\mathrm{T}}$ is an obligate chemo-organotroph. No growth was detected on mineral media complemented with vitamins, sulfur with an $\mathrm{H}_{2} / \mathrm{CO}_{2}(80: 20)$ headspace. Growth was observed both on proteinaceous substrates and on carbohydrates. BHI or gluten successfully supported growth, final concentrations being between $5 \times 10^{7}$ and $5 \times 10^{8}$ cells $\mathrm{ml}^{-1}$. Final concentrations from $2 \times 10^{7}$ to $5 \times 10^{7}$ cells ml ${ }^{-1}$ were reached with yeast extract. Peptone and tryptone were also used at $1 \mathrm{~g} \mathrm{l}^{-1}$, but only in the presence of $0.5 \mathrm{~g}$ yeast extract $1^{-1}$. The corresponding final concentrations were greater than $10^{8}$ cells $\mathrm{ml}^{-1}$. The other proteinaceous carbon sources tested did not support growth. When $0 \cdot 1 \mathrm{~g}$ yeast extract $1^{-1}$ was added, growth was observed on $\mathrm{D}(+)$-glucose, $\mathrm{D}(-)$-fructose, maltose, $\mathrm{D}(+)$-cellobiose and $\mathrm{D}(+)$-sucrose, final cell concentrations being from $5 \times 10^{7}$ to $10^{8}$ cells ml ${ }^{-1}$ for D (+)-sucrose and $2 \times 10^{7}-5 \times 10^{7}$ cells $\mathrm{ml}^{-1}$ for the other sugars. Isolate $\mathrm{MV} 1075^{\mathrm{T}}$ also used polysaccharides such as starch, cellulose, carboxymethylcellulose, pectin and chitin, but not xylan or dextran. Among the acids and alcohols tested, significant growth was detected only on pyruvate. Yeast extract was the only nitrogen source tested that supported growth in combination with glucose. The final cell concentrations reached in the controls without added carbon or nitrogen sources ranged from $5 \times 10^{6}$ to $2 \times 10^{7}$ cells $\mathrm{ml}^{-1}$. Maximum growth rates and cell yields were achieved in YGS medium. Under optimal

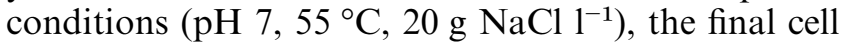
density was over $2 \times 10^{8}$ cells ml $\mathrm{m}^{-1}$ after $12 \mathrm{~h}$ and $5 \times 10^{8}$ cells $\mathrm{ml}^{-1}$ after $48 \mathrm{~h}$. The doubling time was around

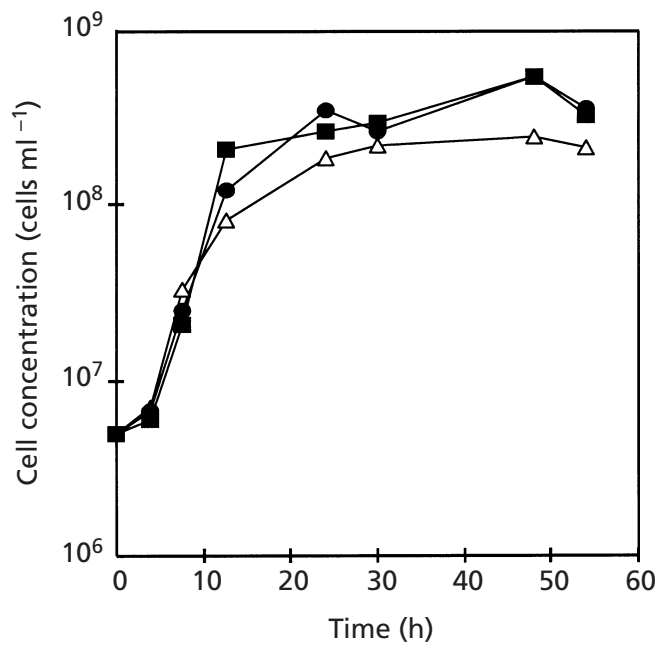

Fig. 4. Effects of sulfur ( $\boldsymbol{\square})$ and cystine (0) on the cell concentration during growth of $\mathrm{MV} 1075^{\top}$ on YGS medium. The control curve was obtained in medium without sulfur or cystine $(\triangle)$.

$1.7 \mathrm{~h}$. During growth, the concentrations of arginine, isoleucine, leucine and phenylalanine decreased in YGS medium, whereas the concentrations of alanine, proline and lysine increased. Glucose was consumed and acetate, lactate, isovalerate and isobutyrate were produced. $\mathrm{H}_{2}, \mathrm{CO}_{2}$ and $\mathrm{H}_{2} \mathrm{~S}$ (absent in the uninoculated control) were detected. Hydroxyphenylacetate and phenylacetate were produced at concentrations of less than $0.01 \mathrm{mM}$. When glucose (medium YGS) was replaced by tryptone (medium YTS), indole3 -acetate was produced and the concentrations of hydroxyphenylacetate and phenylacetate increased 3fold. Less acetate and lactate but more isovalerate and isobutyrate were produced. The proline concentration after $48 \mathrm{~h}$ in YTS medium was 7-fold higher than that in YGS medium. In cultures on YGS and YTS media, the concentrations of arginine decreased dramatically.

\section{Effect of electron acceptors and influence of the gas headspace}

The addition of thiosulfate or polysulfides to the culture medium did not stimulate growth. A small increase in the final cell concentration was obtained with L-cystine and sulfur (Fig. 4). After $24 \mathrm{~h}$ in the presence of elemental sulfur, $2 \cdot 5$-fold more acetate and $5 \cdot 5$-fold more alanine were produced and 4-fold more glucose and 8-fold more leucine were consumed. In the presence of L-cystine, 3-fold more acetate and 10-fold more alanine were produced and $6 \cdot 5$-fold more glucose and 6.5-fold more leucine were consumed. Of the amino acids and organic acids, the concentrations of alanine, leucine and acetate were those most affected by growth of the strain. Growth was not affected when the gas headspace was replaced by $\mathrm{N}_{2}$ or $\mathrm{N}_{2} / \mathrm{CO}_{2}$ 


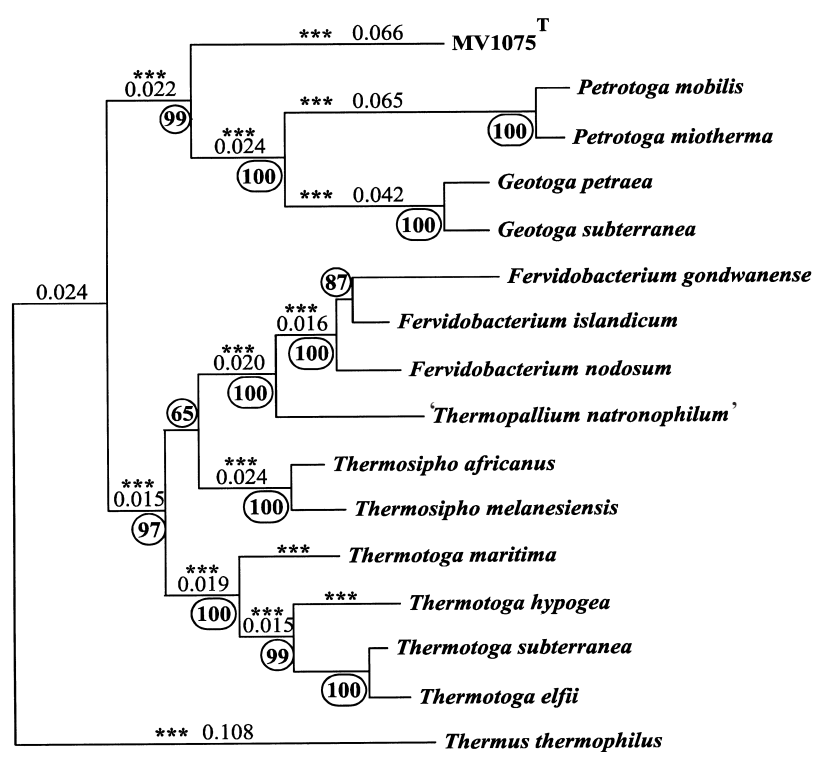

Fig. 5. Phylogenetic position of strain $M V 1075^{\top}$ within the order Thermotogales; 1017 sites were used for the phylogenetic analysis. Alignment was performed with representatives of the genera Fervidobacterium, Thermotoga, Thermosipho, Geotoga and Petrotoga. Thermus thermophilus was chosen as the outgroup. The topology shown is an unrooted tree obtained with a neighbour-joining algorithm (Jukes-Cantor corrections) established using PHYLO_WIN and performed manually with SEAVIEW. Bootstrap percentages are encircled and evolutionary distances are presented on the branches. Branches labelled with triple asterisks have been confirmed by maximum-likelihood and parsimony methods. Bar, 4.7 nucleotide substitutions per 100 nucleotides.

(80:20), but it was strongly inhibited by $\mathrm{H}_{2} / \mathrm{CO}_{2}$ $(80: 20)$. Inhibition by $\mathrm{H}_{2}$ was partially eliminated by the addition of sulfur, but the growth rate remained lower than those obtained with the other headspace gases: after $8.5 \mathrm{~h}$, the concentration was $2.7 \times 10^{7}$ cells ml ${ }^{-1}$ with $\mathrm{H}_{2} / \mathrm{CO}_{2}(80: 20)$ and $7 \times 10^{7}-$ $1.5 \times 10^{8}$ with the other headspace gases. In all cases, when elemental sulfur was present in the culture medium, growth of strain MV1075 ${ }^{\mathrm{T}}$ was accompanied by the production of $\mathrm{H}_{2} \mathrm{~S}$, which was not detected in the uninoculated control incubated in the same conditions.

\section{Susceptibility to antibiotics}

Growth of isolate $\mathrm{MV} 1075^{\mathrm{T}}$ was inhibited by the addition of streptomycin, vancomycin, chloramphenicol, rifampicin and penicillin $\mathrm{G}$ (at $25 \mu \mathrm{g} \mathrm{ml}^{-1}$ in each case). The strain was not sensitive to kanamycin at $100 \mu \mathrm{g} \mathrm{ml}{ }^{-1}$.

\section{DNA base composition}

The $\mathrm{G}+\mathrm{C}$ content of the DNA of isolate MV1075 was $29 \pm 1 \mathrm{~mol} \%$.

\section{S rDNA sequence analysis}

Comparisons (using BLAST) with 16S rDNA sequences available in GenBank revealed that isolate MV1075 belonged to the order Thermotogales. Consequently, the 16S rDNA sequences of strain MV1075 ${ }^{\mathrm{T}}$ and 14 representatives of the order Thermotogales were compared. The sequence of MV1075 $5^{\mathrm{T}}$ grouped with the Geotoga/Petrotoga lineage with all three algorithms used (neighbour-joining, maximum-parsimony and maximum-likelihood), having corresponding bootstrap values of 99 or $100 \%$ (Fig. 5). The level of $16 \mathrm{~S}$ rDNA sequence similarity between strain MV1075 and the other strains was less than $83 \%$ in all cases. The highest $16 \mathrm{~S}$ rDNA sequence similarity, $82 \%$, was to G. petraea, G. subterranea and Thermotoga maritima.

\section{DISCUSSION}

The novel, marine, thermophilic strain MV1075 belongs to the bacterial domain according to its sensitivity to antibiotics and its $16 \mathrm{~S}$ rDNA sequence. The major physiological traits of isolate $\mathrm{MV} 1075^{\mathrm{T}}$ are consistent with assignment to the order Thermotogales, which includes other anaerobic, thermophilic bacteria. Transmission electron microscopy has shown the presence of an external sheath surrounding the cells, which is a morphological characteristic of the members of this order. The strain is Gram-negative, chemoorganotrophic and able to ferment several sugars and growth is inhibited by $\mathrm{H}_{2}$ in the absence of sulfur. Isolate $\mathrm{MV} 1075^{\mathrm{T}}$ produces L-alanine from glucose fermentation, which has been proposed by Ravot et al. (1996) as an ancestral metabolism shared by the orders Thermotogales and Thermococcales. Thiosulfate and sulfur were both reported to improve the growth rates and cell yields of all members of the Thermotogales tested: F. islandicum, Thermotoga maritima, Thermotoga neapolitana, Thermosipho africanus, Thermotoga elfii (Ravot et al., 1995b), Thermotoga subterranea (Jeanthon et al., 1995), P. mobilis, P. miotherma (Lien et al., 1998) and Thermosipho melanesiensis (Antoine et $a l .$, 1997). In the case of strain MV1075 ${ }^{\mathrm{T}}$, neither sulfur nor thiosulfate had a major stimulatory effect on growth rates and final cell concentrations. Indeed, the most prominent effect of sulfur was on amino acid and organic acid production. The presence of thiosulfate, for some members of the Thermotogales, results in increased production of acetate and decreased production of alanine (Ravot et al., 1996). This metabolic shift, which is linked to the effect of the electron acceptor on $\mathrm{H}_{2}$ concentration, also occurred in the presence of sulfur, but not with thiosulfate, for Thermosipho melanesiensis (isolated from deep-sea hydrothermal vents). This was not observed with isolate $\mathrm{MV} 1075^{\mathrm{T}}$, since, in the presence of sulfur, more alanine - but also more acetate - was produced. Of the genera within the order Thermotogales, MV1075 ${ }^{\mathrm{T}}$ is closest to the genera Petrotoga and Geotoga. MV1075 and the species of Petrotoga and Geotoga are moderate thermophiles with optimum temperatures between 45 
and $60{ }^{\circ} \mathrm{C}$. The other species of the Thermotogales grow optimally at temperatures above $65^{\circ} \mathrm{C}$. Furthermore, phylogenetic analysis based on 16S rDNA showed a stronger affiliation to the species of Geotoga and Petrotoga than to other species. Unlike the growth of species isolated from oil wells, such as $P$. mobilis or $P$. miotherma, growth of MV1075 ${ }^{\mathrm{T}}$ is not stimulated by thiosulfate. The effect of thiosulfate on the growth of Geotoga spp. has never been reported. Unlike the species of Petrotoga and Geotoga, which are described as fermentative bacteria able to grow on various polysaccharides, isolate MV1075 ${ }^{\mathrm{T}}$ is capable of growth on both sugars and proteinaceous substrates. The salinity range for growth of species belonging to the genera Petrotoga and Geotoga is much wider $(0 \cdot 5-9 \%$, $\mathrm{w} / \mathrm{v}, \mathrm{NaCl})$ than the salinity range of $\mathrm{MV} 1075^{\mathrm{T}}$ $(1-4.5 \%, \mathrm{w} / \mathrm{v}, \mathrm{NaCl})$. This can be correlated with their respective origins: brines from oilfields for Geotoga and Petrotoga species, deep-sea hydrothermal vents for MV1075 ${ }^{\mathrm{T}}$. MV1075 is well adapted to a salinity of $2 \%(\mathrm{w} / \mathrm{v}) \mathrm{NaCl}$ because of its marine origin. Unlike that of isolate MV1075 $5^{\mathrm{T}}$, the generation times of the Geotoga and Petrotoga species are long: $7 \mathrm{~h}$ for $P$. miotherma and more than $10 \mathrm{~h}$ for the other species. Because of the evolutionary distance between strain MV1075 $5^{\mathrm{T}}$ and the species of the genera Geotoga and Petrotoga, its shorter generation time, its deep-marine origin and the physiological differences, we propose that $\mathrm{MV} 1075^{\mathrm{T}}$ should be assigned to a new genus within the order Thermotogales.

\section{Description of Marinitoga Wery, Cambon-Bonavita, Godfroy and Barbier gen. nov.}

Marinitoga (Ma.ri.ni.to'ga. L. n. marinus of the sea; L. fem. n. $\operatorname{tog} a$ Roman outer garment; N.L. fem. n. Marinitoga a marine toga, referring to the marine isolation of the organism and the presence of a 'toga'like sheath).

Cells are rod-shaped with a sheath-like outer structure, motile with polar flagella and stain Gram-negative. Cell division occurs by constriction. Moderate thermophile, adapted to the $\mathrm{pH}$ and salinity of ocean. Anaerobic, chemo-organotrophic and able to ferment a broad spectrum of carbohydrates and proteinaceous substrates. Sulfur is not essential for growth. The presence of sulfur prevents inhibition by $\mathrm{H}_{2}$, and $\mathrm{H}_{2} \mathrm{~S}$ is produced. The $\mathrm{G}+\mathrm{C}$ content is $29 \mathrm{~mol} \%$. $16 \mathrm{~S}$ rDNA sequence comparisons locate Marinitoga in the bacterial domain, within the order Thermotogales, close to the Geotoga/Petrotoga lineage. The type species is Marinitoga camini.

\section{Description of Marinitoga camini Wery, Cambon- Bonavita, Godfroy and Barbier sp. nov.}

Marinitoga camini (ca'mi.ni. L. gen. n. camini of a chimney, relating to its isolation from a hydrothermal chimney).

Cells are rod-shaped with a sheath-like outer structure, motile with polar flagella and stain Gram-negative.
Under optimal conditions, cells appear as short rods (2-3 $\mu \mathrm{m}$ long by $0.5-1 \mu \mathrm{m}$ wide), singly, in pairs or in short chains (of fewer than five cells). Spherical bodies are formed in the stationary phase. Grows at $25-65^{\circ} \mathrm{C}$ (optimum at $55^{\circ} \mathrm{C}$ ), at $\mathrm{pH} 5-9$ (optimum at $\mathrm{pH}$ 7) and in 15-70 g sea salt $1^{-1}$, corresponding to $10-45 \mathrm{~g} \mathrm{NaCl}$ $1^{-1}$ (optimum at $30 \mathrm{~g}$ sea salt $\mathrm{l}^{-1}$, corresponding to $20 \mathrm{~g}$ $\mathrm{NaCl}^{-1}$ ). The doubling time under optimal conditions is $1.7 \mathrm{~h}$ and the maximum cell yield is $2 \times 10^{8}$ cells ml $\mathrm{ml}^{-1}$. Anaerobic. Chemo-organotrophic. Able to ferment gluten, BHI, peptone, tryptone, sucrose, glucose, fructose, maltose and cellobiose in the presence of yeast extract. $\mathrm{CO}_{2}, \mathrm{H}_{2}$, acetate, isovalerate and isobutyrate are formed during glucose fermentation. The $\mathrm{G}+\mathrm{C}$ content is $29 \pm 1 \mathrm{~mol} \%$. The $16 \mathrm{~S}$ rDNA similarity to Geotoga petraea and Geotoga subterranea is $82 \%$. Isolated from chimney rocks collected from the Menez-Gwen hydrothermal site on the Mid-Atlantic Ridge $\left(31^{\circ} 31^{\prime} \mathrm{W}, 37^{\circ} 51^{\prime} \mathrm{N}\right.$; depth $\left.980 \mathrm{~m}\right)$. The type strain is $\mathrm{MV} 1075^{\mathrm{T}} \quad\left(=\mathrm{CNCM} \quad \mathrm{I}-2413^{\mathrm{T}}=\mathrm{DSM}\right.$ $\left.13578^{\mathrm{T}}\right)$.

\section{ACKNOWLEDGEMENTS}

We thank the chief scientists of the French oceanographic cruise MARVEL (1997), Daniel Desbruyères and AnneMarie Alayse (IFREMER, Centre de Brest, France), the captain and crew of N.O. Atalante and the D.S.V. Nautile pilots and support crew. We gratefully acknowledge Philippe Crassous (IFREMER) for assistance with the scanning electron microscopy and Anne Donval (Institut Universitaire d'Etudes sur la Mer, Laboratoire d'Environnement Marin, Brest, France) and Gerard Sinquin (Université de Bretagne Occidentale, UFR Sciences, Brest, France) for assistance with the transmission electron microscopy. This research was undertaken within the framework of the AMORES Project. We acknowledge support from the European Commission's Marine Science and Technology Program (MAST III) under contract MAST3-CT95-0040. This work was also supported by the French Research Ministry and Région Bretagne.

\section{REFERENCES}

Altschul, S. F., Gish, W., Miller, W., Myers, E. W. \& Lipman, D. J. (1990). Basic local alignment search tool. J Mol Biol 215, 403-410.

Andrews, K. T. \& Patel, B. K. C. (1996). Fervidobacterium gondwanense sp. nov., a new thermophilic anaerobic bacterium isolated from nonvolcanically heated geothermal waters of the Great Artesian Basin of Australia. Int J Syst Bacteriol 46, 265-269.

Antoine, E., Guezennec, J., Meunier, J. R., Lesongeur, F. \& Barbier, G. (1995). Isolation and characterization of extremely thermophilic archaea related to the genus Thermococcus from deep-sea hydrothermal Guaymas basin. Curr Microbiol 31, 186-192.

Antoine, E., Cilia, V., Meunier, J. R., Guezennec, J., Lesongeur, F. \& Barbier, G. (1997). Thermosipho melanesiensis sp. nov., a new thermophilic anaerobic bacterium belonging to the order Thermotogales, isolated from deep-sea hydrothermal vents in the southwestern Pacific Ocean. Int J Syst Bacteriol 47, 1118-1123.

Balch, W. E., Fox, G. E., Magrum, L. J., Woese, C. R. \& Wolfe, R. S. 
(1979). Methanogens: reevaluation of a unique biological group. Microbiol Rev 43, 260-296.

Bertoldo, C., Duffner, F., Jorgensen, P. L. \& Antranikian, G. (1999). Pullulanase type I from Fervidobacterium pennavorans Ven5: cloning, sequencing, and expression of the gene and biochemical characterization of the recombinant enzyme. Appl Environ Microbiol 65, 2084-2091.

Blumentals, I. I., Itoh, M., Olson, G. J. \& Kelly, R. M. (1990). Role of polysulfides in reduction of elemental sulfur by the hyperthermophilic archaeon Pyrococcus furiosus. Appl Environ Microbiol 56, 1255-1262.

Canganella, F., Andrade, C. M. \& Antranikian, G. (1994). Characterization of amylolytic and pullulytic enzymes from thermophilic archaea and from a new Fervidobacterium species. Appl Microbiol Biotechnol 42, 239-245.

Davey, M. E., Wood, W. A., Key, R., Nakamura, K. \& Stahl, D. A. (1993). Isolation of three species of Geotoga and Petrotoga: two new genera, representing a new lineage in the bacterial line of descent distantly related to the 'Thermotogales'. Syst Appl Microbiol 16, 191-200.

Duckworth, A. W., Grant, W. D., Jones, B. E. \& Van Steenbergen, R. (1996). Phylogenetic diversity of soda lake alkaliphiles. FEMS Microbiol Ecol 19, 181-191.

Duffaud, G. D., McCutchen, C. M., Leduc, P., Parker, K. N. \& Kelly, R. M. (1997). Purification and characterization of extremely thermostable $\beta$-mannanase, $\beta$-mannosidase, and $\alpha$ galactosidase from the hyperthermophilic eubacterium Thermotoga neapolitana 5068. Appl Environ Microbiol 63, 169-177.

Felsenstein, J. (1981). Evolutionary trees from DNA sequences: a maximum likelihood approach. J Mol Evol 17, 368-376.

Felsenstein, J. (1985). Confidence limits on phylogenies: an approach using the bootstrap. Evolution 30, 783-791.

Friedrich, A. B. \& Antranikian, G. (1996). Keratin degradation by Fervidobacterium pennavorans, a novel thermophilic anaerobic species of the order Thermotogales. Appl Environ Microbiol 62, 2875-2882.

Galtier, N., Gouy, M. \& Gautier, C. (1996). SEAVIEW and PHYLO_WIN: two graphic tools for sequence alignment and molecular phylogeny. Comput Appl Biosci 12, 543-548.

Godfroy, A., Lesongeur, F., Raguénès, G., Quérellou, J., Antoine, E., Meunier, J.-R., Guezennec, J. \& Barbier, G. (1997). Thermococcus hydrothermalis sp. nov., a new hyperthermophilic archaeon isolated from a deep-sea hydrothermal vent. Int J Syst Bacteriol 47, 622-626.

Huber, R. \& Stetter, K. O. (1992). The Thermotogales: hyperthermophilic and extremely thermophilic bacteria. In Thermophilic Bacteria, pp. 186-194. Edited by J. K. Kristjansson. Boca Raton, FL: CRC Press.

Huber, R., Langworthy, T. A., König, H., Thomm, M., Woese, C. R., Sleytr, U. B. \& Stetter, K. O. (1986). Thermotoga maritima sp. nov., represents a new genus of unique extremely thermophilic eubacteria growing up to $90^{\circ} \mathrm{C}$. Arch Microbiol 144, 324-333.

Huber, R., Woese, C. R., Langworthy, T. A., Fricke, H. \& Stetter, K. O. (1989). Thermosipho africanus gen. nov. represents a new genus of thermophilic eubacteria within the 'Thermotogales'. Syst Appl Microbiol 12, 32-37.

Huber, R., Woese, C. R., Langworthy, T. A., Kristjansson, J. K. \& Stetter, K. O. (1990). Fervidobacterium islandicum sp. nov., a new extremely thermophilic eubacterium belonging to the 'Thermotogales'. Arch Microbiol 154, 105-111.
Jannasch, H. W., Huber, R., Belkin, S. \& Stetter, K. O. (1988). Thermotoga neapolitana sp. nov. of the extremely thermophilic, eubacterial genus Thermotoga. Arch Microbiol 150, 103-104.

Jeanthon, C., Reysenbach, A.-L., L'Haridon, S., Gambacorta, A., Pace, N. R., Glénat, P. \& Prieur, D. (1995). Thermotoga subterranea sp. nov., a new thermophilic bacterium isolated from a continental oil reservoir. Arch Microbiol 164, 91-97.

Lake, J. A. (1987). A rate-independent technique for analysis of nucleic acid sequences: evolutionary parsimony. Mol Biol Evol 4, 167-191.

Liebl, W., Ruile, P., Bronnenmeier, K., Riedel, K., Lottspeich, F. \& Greif, I. (1996). Analysis of a Thermotoga maritima DNA fragment encoding two similar thermostable cellulases, CelA and $\mathrm{CelB}$, and characterization of the recombinant enzymes. Microbiology 142, 2533-2542.

Lien, T., Madsen, M., Rainey, F. A. \& Birkeland, N.-K. (1998). Petrotoga mobilis sp. nov., from a North Sea oil-production well. Int J Syst Bacteriol 48, 1007-1013.

Marmur, J. \& Doty, P. (1962). Determination of the base composition of desoxyribonucleic acid from its thermal denaturation temperature. J Mol Biol 5, 109-118.

Marteinsson, V. T., Birrien, J.-L. \& Prieur, D. (1997). In situ enrichment and isolation of thermophilic micro-organisms from deep-sea hydrothermal environments. Can J Microbiol 43, 694-697.

Patel, B. K. C., Morgan, H. W. \& Daniel, R. M. (1985). Fervidobacterium nodosum gen. nov. and spec. nov., a new chemoorganotrophic, caldoactive, anaerobic bacterium. Arch Microbiol 141, 63-69.

Raguénès, G., Pignet, P., Gauthier, G., Peres, A., Christen, R., Rougeaux, H., Barbier, G. \& Guézennec, J. (1996). Description of a new polymer-secreting bacterium from a deep-sea hydrothermal vent, Alteromonas macleodii subsp fijiensis, and preliminary characterization of the polymer. Appl Environ Microbiol 62, 67-73.

Raguénès, G., Christen, R., Guezennec, J., Pignet, P. \& Barbier, G. (1997). Vibrio diabolicus sp. nov., a new polysaccharidesecreting organism isolated from a deep-sea hydrothermal vent polychaete annelid, Alvinella pompejana. Int J Syst Bacteriol 47, 989-995.

Ravot, G., Magot, M., Fardeau, M.-L., Patel, B. K. C., Prensier, G., Egan, A., Garcia, J.-L. \& Ollivier, B. (1995a). Thermotoga elfii sp. nov., a novel thermophilic bacterium from an African oilproducing well. Int J Syst Bacteriol 45, 308-314.

Ravot, G., Ollivier, B., Magot, M., Patel, B. K. C., Crolet, J.-L., Fardeau, M.-L. \& Garcia, J.-L. (1995b). Thiosulfate reduction, an important physiological feature shared by members of the order Thermotogales. Appl Environ Microbiol 61, 2053-2055.

Ravot, G., Ollivier, B., Fardeau, M.-L., Patel, B. K. C., Andrews, K. T., Magot, M. \& Garcia, J.-L. (1996). L-Alanine production from glucose fermentation by hyperthermophilic members of the domains Bacteria and Archaea: a remnant of an ancestral metabolism? Appl Environ Microbiol 62, 2657-2659.

Saitou, M. \& Nei, M. (1987). The neighbor-joining method: a new method for reconstructing phylogenetic trees. Mol Biol Evol 4, 406-425.

Sunna, A. \& Antranikian, G. (1996). Growth and production of xylanolytic enzymes by the extreme thermophilic anaerobic bacterium Thermotoga thermarum. Appl Microbiol Biotechnol 45, 671-676.

Thompson, J. D., Higgins, D. G. \& Gibson, T. J. (1994). CLUSTAL 
W: improving the sensitivity of progressive multiple sequence alignment through sequence weighting, position-specific gap penalties and weight matrix choice. Nucleic Acids Res 22, 4673-4680.

Windberger, E., Huber, R., Trincone, A., Fricke, H. \& Stetter, K. O. (1989). Thermotoga thermarum sp. nov. and Thermotoga neapolitana occurring in African continental solfataric springs. Arch Microbiol 151, 506-512.

Zverlov, V. V., Volkov, I. Y., Velikodvorskaya, T. V. \& Schwarz, W. H. (1997). Thermotoga neapolitana bglB gene, upstream of lam $A$, encodes a highly thermostable $\beta$-glucosidase that is a laminaribiase. Microbiology 143, 3537-3542. 